\title{
Glinical Studies on Adrenocorticotropic Hormone (ACTH) in Human Plasma
}

\author{
Part II. Effects of Adrenal Cortical Inhibitor, SU-4885, and Physical Stress \\ on Plasma ACTH and the Diurnal Variation of Plasma ACTH
}

\section{Shigeru MATSUKURA}

\author{
Second Division, Department of Internal Medicine, Kyoto University School of Medicine
}

(Director : Professor Masaichi Fukase, M.D.)

Plasma ACTH was determined by a modification of the method of Lipscomb and Nelson (femoral method) but, in some cases, test materials were injected into the aorta (aortic method).

1) After the oral administration of SU-4885, 3.0 g. per one day, plasma ACTH rose to a mean士standard error (S.E.), $1.6 \pm 0.4 \mathrm{mU} / 100 \mathrm{ml}$, ranging from 0.6 to $4.0 \mathrm{mU}$ per $100 \mathrm{ml}$. in 9 endocrinologically normal subjects. In 5 patients after long-term steroid treatments plasma ACTH was not detectable except in one case. All 5 patients with anorexia nervosa had distinctly elevated ACTH levels after the administration of SU-4885. Two of 5 patients with anorexia nervosa showed more than normal rises both in plasma ACTH and in urinary 17-OHCS excretion. In 2 patients with Gushing's syndrome due to adrenal cortical hyperplasia no detectable ACTH in plasma was found, whereas one patient with Gushing's syndrome due to adrenal cortical adenoma had an elevated ACTH level after the administration of SU-4885, who showed good response to ACTH . However, no ACTH was detected in one unilaterally adrenalectomized patient for a adrenal cortical adenoma, even 2 years after an operation. Elevated ACTH levels were also noted in one patient with liver cirrhosis and one patient with Laurence-Moon-Biedle's syndrome. Generally, the elevated plasma AGTH levels were associated with high values of urinary 17-OHCS excretion, although there were several exceptional cases.

2) In 8 of 13 patients undergoing a major operation, such as laparotomy or thoracotomy, plasmas obtained one hour after the incision were found to have elevated ACTH levels ranging from 0.6 to $19.1 \mathrm{mU}$ per $100 \mathrm{ml}$ of plasma, which returned toward nondetectable levels within 24 hours postoperatively with the exception of one case. It was noted that increases in plasma AGTH occurred coincident with elevations in plasma cortisol when both were measured simultaneously in 6 cases. Plasma from two schizophrenic patients receiving electroconvulsive therapy was found to contain elevated ACTH levels.

3) The normal diurnal rhythm of plasma ACTH, that is, the rise in the early morning and the decline in the evening was noted in normal subjects, whereas it was absent in patients with Cushing's syndrome due to adrenal cortical hyperplasia. On the other hand, 4 patients 'wiht adrenogenital syndrome and 10 patients with Addison's disease maintained the diurnal variation, showing greater differences than normal subjects between plasma ACTH levels in the early morning and those in the evening. (pp. 516 526) 


\title{
血中 ACTH に関する臨床的研究
}

\author{
第二編 副腎皮質抑制剂（SU-4885）およびストレスの血中 ACTH \\ への影響ならびに ACTH の日内変動について
}

\author{
京都大学医学部内科第二講座 (指導 深瀨政市教授) \\ 松食茂
}

(昭和 41 年 10 月 15 日受付)

1 緒言

下垂体よりの Adrenocorticotropic Hormone (ACTH) の分泌調節には現在三つの因子が関与している ものと考觉られている ${ }^{14) 22}$. その第一は血中の Cortisol 值の変化による Feedback 機構とよばれている るの, 第二は種々の身体的または精神的ストレス, 第三は日内変動である。従つて下垂体よりのACTH 分 泌の動態を詳細に知るためには, Feedback 機構, ストレスによる分泌機構, 日内变動の機構を解明する 必要がある。

近年 Amphenone B の誘導体である SU-4885 は Feedback 機構を介して ACTH の分泌增加を起こ

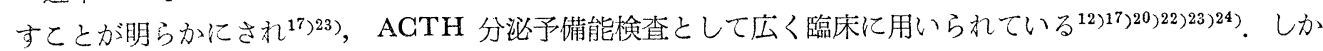
しこの方法は一般㨽腎皮質ホルモンの代謝産物 17-OHCS 又は 17-KGS を測定する間接的な検査法であ $\eta$, SU-4885 投与時の ACTH 分泌の動態に関してはなお知兒が乏しい.

ストレスによる ACTH の分泌をみるために種々の方法 $\left.{ }^{18}\right)^{19}$ があるが，最も強力なストレスは外科的侵 襲る7である。徤つて大手術時の血中 ACTH の変動を血中ステロイドの変動とともに観察することは，ス トレスの際の ACTH 分泌機構衣明らかにする重要な手がかりとなる。

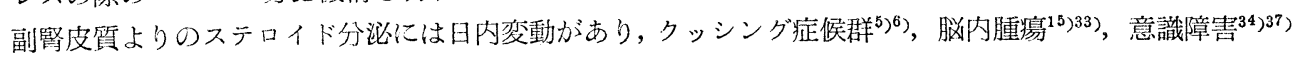
などではそれが消失することはかなり古くより知られていたが，乙の日内変動が ACTH 分泌の変動に基

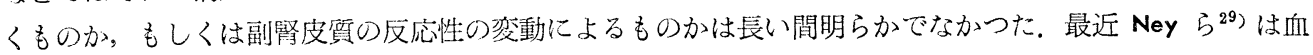
中 17-OHCS の変動と平行して血中 ACTH 值にも変動が起こるてとを明らかにした。しかしACTH 分 泌潩常をきたすような各種内分泌疾患で日内変動が保たれているかいなかはなお充分明らかでない.

著者はすでに第一編で各種内分泌疾患における血中 ACTH 值について報告したが，本編では SU-4885 投与, 手術侵襲や電気ショックなどのストレスの血中 ACTH 值への影響を観察するとともに, ACTH 分 泌の日内変動についても検討したのでその成績を報告する。

\section{2 実 験 方 法}

\section{a. 実験対象および試料の採取法}

(1) SU-4885 投与：正常人 9 例，Table 1 亿示したような各種滛患に長期に副腎皮質ステロイドを投与 した後の 5 例, 神経性食思不振症 5 例，Laurence-Moon-Biedle 症候群 1 例，早発性青春期症 1 例，低性腺

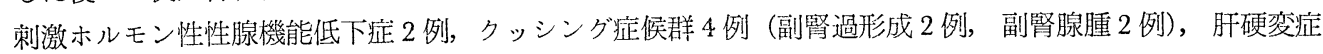
1 例, 粘液水腫 1 例, 異常色素沈着症 1 例, 計30例てついて SU-4885 試験をおてなつた。患者はその大部 分が京都大学附属病院内科中病舎に入院中のものであつた. SU-4885 $3.0 \mathrm{~g}$ を 6 回分割, 午前 9 時より 4 時間毎に投与した。 ACTH 測定のための採血は投与開始24時間後に行なつた。 また投与前 2 日，投与当 日，投与中止後 2 日全尿を採取し尿中 17-OHCS の測定をおてなつた。

(2) ストレス: 京都大学附属病院外科北病舎, 同南病舎, 結核研究所外科病舎に入院した13例を対象にし た. 年令, 性別, 手術術式, 手術時間, 麻酔薬品は Table 2 に示すでとくである. 各症例とも術前に 
Morphine 剂の投与をうけている. 手術室に入る直前, 執刀開始 1 時間後, 24 時間後の三回採血し, 血中 AGTH，一部の症例では血中 Cortisol を同時に測定した. また京都大学附属病院精神科病舎に入院中の精 神分裂症患者 2 例では電気ショック施行15分後に採血し, 血中 ACTH, 血中 Cortisol の測定を行なつた. なお 2 例ともイソゾールの前処置をうけていた.

（3）日内変動：正常人 3 例, 副腎皮質過形成によるクッシング症候群 4 例, 副腎性器症候群 4 例, アシソ ン病10例について午前 8 時, 午後 6 時の 2 回にわたり採血し，血中 ACTH，一部の症例では同 時に血中 Cortisol を測定した。 なおすでに治療を受けていた副腎性器症候群, アシシソン病の症例では一週間から数力 月にわたり補償療法を中止した後測定を行なつた.

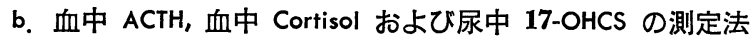

血中 ACTH の測定は第一編に述べた方法に従つた. しかしながら本方法では血中 AGTH の正常值ま たはこれに近い值を測定するには感度が充分でないために，日内変動に関する血中 ACTH の測定には一部 次のごとき改良をおてなつた. すなわち下垂体摘出 2 時間後のラットを用いまず開腹の後カテーテルを大動 脈に挿入，その尖端を副腎動脈の分岐している高さまで到達せしめて試料を注入，注入 6 分後より12分間左 副腎静脈に挿入したカテーテルにより採血し，その Corticosterone 含量を測定した。本方法により・USP Reference AGTH の $0.01 \mathrm{mU}$ まで測定が可能で, 血漿 $5.0 \mathrm{ml}$ を注入した場合 $0.2 \mathrm{mU} / 100 \mathrm{ml}$ plasma の あたりまで測定可能となつた. 用量 $\mathrm{X}$ 反応量 $\mathrm{Y}$ の間には $\mathrm{Y}=1.97 \log \mathrm{X}+4.34$ なる関係式が成立し, 精度 指数入は0.30であつた。尿中 17-OHCS は教室の佐古により, Reddy, Jenkins and Thorn の変法を用いて測 定された. また血中 Cortisol はV Van der Vies の変法を用い教室の本田によつて測定された.

\section{3 実 験 成 績}

\section{SU-4885 投与の血中 ACTH 值への影響}

内分泌学的に正常な 9 例における SU-4885 投与後の血中 ACTH 值および尿中 17-OHCS 排泄值は Table 1 に示すとおりである.なお SU-4885 投与前には正常人では本法によつては血中 ACTH 活性を検 出できないため, いずれの症例でも投与前值の測定は行なわなかつた. SU-4885 投与後の血中 ACTH 值 は 0.6〜 4.0mU/100ml plasma で, 平均值士標準䛊差は $1.6 \pm 0.4 \mathrm{mU} / 100 \mathrm{ml}$ plasma であつた. 副腎皮質ステ ロイド投与群はいずれも約 4 カ月から約 4 年間にわたりステロイドの投与をうけた症例であつたが，SU4885投与後 5 例中 4 例に AGTH 活性の明らかな増加を罳めなかつた. (Table 1). 神経性食思不振症 5 例 ではいずれも SU-4885 投与後血中 ACTH 值の増加を認め, 症例 K.S., K.A. ではとくに著明な増加がみ られた。. また尿中 17-OHCS の増加もてれら 2 例では著明であつた (Table 1). クッシング症候群のうち 副腎皮質過形成による 2 例ではいずれも血中 ACTH 值の増加を証明できなかつた（Table 1)。乙れに対

Table 1. Plasma ACTH levels after oral administration of SU-4885.

1. Endocrine normal

\begin{tabular}{l|c|c|c|c|c}
\hline No. & Name & Age \& Sex & ACTH & $\begin{array}{c}\text { Urinary } \\
\text { 17-OHGS }\end{array}$ & Note \\
\hline \hline 1 & O. N. & $22 \mathrm{M}$ & $0.6 \mathrm{mU} / 100 \mathrm{ml}$ & $13.5 \mathrm{mg} /$ day & \\
2 & S.O. & $23 \mathrm{M}$ & 0.6 & 6.7 & \\
3 & M. K. & $22 \mathrm{M}$ & 0.6 & 8.8 & \\
4 & H. I . & $25 \mathrm{~F}$ & 0.7 & 22.9 & \\
5 & Y.S. & $24 \mathrm{M}$ & 1.6 & 17.3 & \\
6 & S.K. & $31 \mathrm{M}$ & 1.6 & 13.4 & Ulcus Ventriculi \\
7 & A. I . & $23 \mathrm{~F}$ & 1.9 & 18.6 & \\
8 & S.M. & $22 \mathrm{M}$ & 3.2 & 8.0 & \\
9 & H.T. & $27 \mathrm{~F}$ & 4.0 & 19.2 & Pylorus Stenosis \\
\hline
\end{tabular}


2. After withdrawal of corticoid treatment

\begin{tabular}{c|c|c|c|c|l}
\hline \hline No. & Name & Age \& Sex & ACTH & $\begin{array}{c}\text { Urinary } \\
\text { 17-OHCS }\end{array}$ & \multicolumn{1}{|c}{ Note } \\
\hline \hline 1 & S.M. & $37 \mathrm{~F}$ & ND*mU/100ml & $8.6 \mathrm{mg} /$ day & Rheumatoid Arthritis \\
2 & H.Y. & $57 \mathrm{M}$ & N D & 3.9 & Apoplexy \\
3 & Y.K. & $53 \mathrm{M}$ & ND & 18.8 & Rheumatoid Arthritis \\
4 & T.A. & $48 \mathrm{M}$ & 2.0 & 14.1 & Sclerodermia \\
5 & K.S. & $19 \mathrm{~F}$ & ND & 4.4 & Acne Vulgaris \\
\hline
\end{tabular}

3. Anorexia nervosa

\begin{tabular}{c|c|c|c|c|c}
\hline \hline No. & Name & Age \& Sex & ACTH & $\begin{array}{c}\text { Urinary } \\
\text { 17-OHGS }\end{array}$ & Note \\
\hline \hline 1 & M. K. & $17 \mathrm{~F}$ & $1.0 \mathrm{mU} / 100 \mathrm{ml}$ & $12.9 \mathrm{mg} / \mathrm{day}$ & \\
2 & T.N. & $28 \mathrm{~F}$ & 2.1 & 16.4 & \\
3 & A. I. & $38 \mathrm{~F}$ & 2.2 & 16.9 & \\
4. & K. S. & $17 \mathrm{~F}$ & 24.8 & 18.9 & \\
5 & K. A. & $15 \mathrm{~F}$ & 66.4 & 27.2 & \\
\hline
\end{tabular}

4. Cushing's syndrome

\begin{tabular}{l|c|c|c|c|l}
\hline \hline No. & Name & Age \& Sex & ACTH & $\begin{array}{c}\text { Urinary } \\
\text { 17-OHCS }\end{array}$ & \multicolumn{1}{c}{ Note } \\
\hline \hline 1 & Y.N. & $36 \mathrm{~F}$ & N D mU/100ml & $25.2 \mathrm{mg} /$ day & Adrenal Hyperplasia \\
2 & Z.M. & $37 \mathrm{M}$ & N D & 31.8 & Adrenal Hyperplasia \\
3 & K.Ma. & $31 \mathrm{~F}$ & 0.6 & 17.5 & Adrenal Adenoma \\
\hline \multirow{2}{*}{4} & K.Mo. & \multirow{2}{*}{$37 \mathrm{M}$} & N D & 4.5 & 8 mos. after right Adrenalectomy \\
& & ND & 7.3 & 2 yrs. after right Adrenalectomy \\
\hline
\end{tabular}

\begin{tabular}{|c|c|c|c|c|c|}
\hline No. & Name & Age \& Sex & ACTH & $\begin{array}{l}\text { Urinary } \\
\text { 17-OHCS }\end{array}$ & Note \\
\hline 1 & H. Y. & $19 \mathrm{M}$ & $\mathrm{N} \mathrm{DmU} / 100 \mathrm{ml}$ & $7.3 \mathrm{mg} / \mathrm{day}$ & Hypogonadotropic Hypogonadism \\
\hline 2 & S.Y. & $23 \mathrm{M}$ & 0.6 & 17.6 & Hypogonadotropic Hypogonadism \\
\hline 3 & $\mathrm{~K} . \mathrm{A}$. & $14 \mathrm{M}$ & ND & 11.2 & Pubertas Precox \\
\hline 4 & $\mathrm{~K} \cdot \mathrm{W}$. & $12 \mathrm{M}$ & 4.2 & 9.5 & Laurence-Moon-Biedle's Syndrome \\
\hline 5 & T.M. & $29 \mathrm{M}$ & 0.6 & 7.5 & Myxedema \\
\hline 6 & S.M. & $54 \mathrm{M}$ & N D & 9.8 & Abnormal Pigmentation \\
\hline 7 & M.N. & $51 \mathrm{M}$ & 7.8 & $22.8^{* *}$ & Liver Girrhosis \\
\hline
\end{tabular}

\section{*Not Detectable $* * 17-$ KGS}

して副腎皮質腺腫による症例 K.Ma. ではかえつて血中 AGTH の増加を認めたがこの症例は AGTH 試 験にも反応良好で, 手術により正常副腎組織の萎縮はほとんど劷められなかつた。症例 K.Mo. は, 右副腎 腺腫のため副腎摘除術をうけ，術後副腎発症を起しした症例である. 術後 8 カ月， 2 年の 2 回 SU-4885 投 与をおこなつたがいずれも血中 ACTH 值の増加を証明し得なかつた。同時におこなつた ACTH 試験で も 2 回とも反応は不良であつたが，2 年後には 8 カ月後に比較して幾分反応の改善がみられた. その他の疾 患についての結果は Table 1 に示すでとくである. 肝硬変症の1例で著明な血中 AGTH の増加を認めた.

以上の結果をまとめて図示すると Fig. 1 のごとくである. また SU-4885 投与後の尿中 17-OHCS の最大 反応の絶対值と血中 ACTH 值を対比したのが Fig. 2 である. 副腎皮質過形成によるクッシング症候群の 
Fig. 1. Plasma ACTH levels after oral

administration of SU-4885

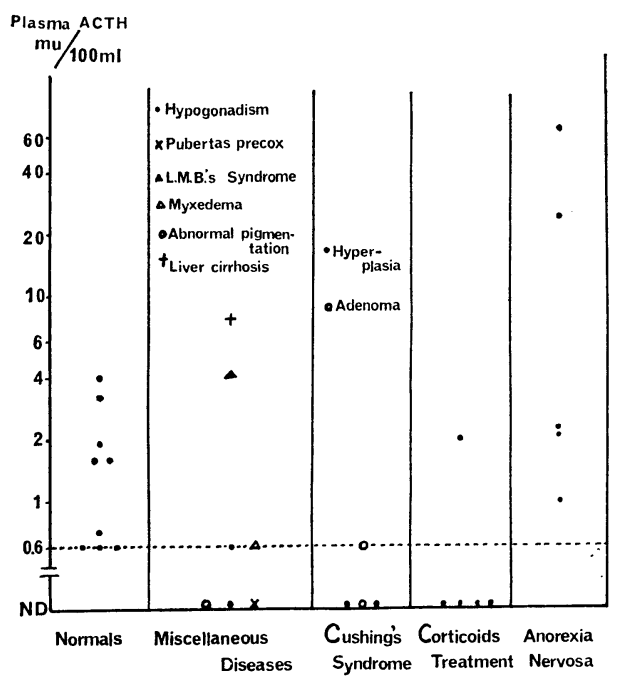

Fig. 2. Relationship between plasma ACTH and urinary 17-OHCS levels after SU-4885 administration ( $3.0 \mathrm{~g}$ per os)

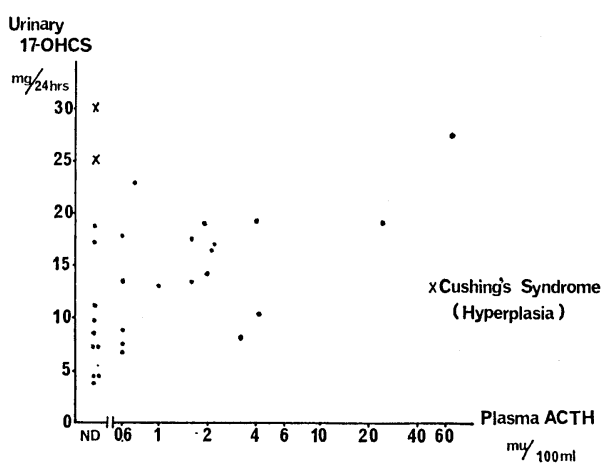

Table 2. Plasma AGTH levels in surgical stress

\begin{tabular}{|c|c|c|c|c|c|c|c|}
\hline \multirow{2}{*}{ Pat. } & \multirow{2}{*}{ Age \& Sex } & \multirow{2}{*}{ Anesthetic } & \multirow{2}{*}{ Operation } & \multirow{2}{*}{ Time } & \multicolumn{3}{|c|}{ Plasma ACTH } \\
\hline & & & & & Preop. $\dagger$ & $1^{\circ}$ p.op. $\dagger^{\dagger} \dagger$ & $24^{\circ}$ p.op. $\dagger \dagger$ \\
\hline $\mathrm{S} \cdot \mathrm{N}$. & $53 \mathrm{M}$ & G.O.F.* & Lobectomy & $3^{\circ} 30^{\prime}$ & ND & 19.1 & $\mathrm{ND}$ \\
\hline M. T. & $53 \mathrm{M}$ & G.O.F. & Lobectomy & $3^{\circ} 10^{\prime}$ & $\mathrm{ND}$ & 1.0 & 0.6 \\
\hline N.H. & $41 \mathrm{M}$ & G.O.F. & Thoraco-plasty & $3^{\circ}$ & ND & 0.8 & ND \\
\hline H.N. & $40 \mathrm{M}$ & G.O.F. & Thoracotomy & $1^{\circ} 50^{\prime}$ & ND & 0.7 & $\mathrm{ND}$ \\
\hline S.O. & $26 \mathrm{M}$ & G.O.F. & Lobectomy & $3^{\circ} 50^{\prime}$ & ND & 0.9 & ND \\
\hline H.N. & $48 \mathrm{~F}$ & G.O.F. & Thoraco-plasty & $1^{\circ} 40^{\prime}$ & ND & 2.3 & ND \\
\hline K. I . & $27 \mathrm{M}$ & G.O.F. & Splenectomy & $2^{\circ} 40^{\prime}$ & ND & 0.6 & ND \\
\hline $\mathrm{T} \cdot \mathrm{T}$. & $35 \mathrm{~F}$ & G.O.E.** & Adrenalectomy & $2^{\circ} 05^{\prime}$ & ND & 0.6 & ND \\
\hline T.S. & $20 \mathrm{M}$ & G.O.F. & Lobectomy & $4^{\circ}$ & ND & ND & ND \\
\hline $\mathrm{Y} . \mathrm{K}$. & $58 \mathrm{M}$ & G.O.F. & Subtotal Gastrectomy & $2^{\circ} 30^{\prime}$ & ND & ND & $\mathrm{ND}$ \\
\hline T.O. & $60 \mathrm{M}$ & G.O.F. & Gastrectomy & $2^{\circ} 15^{\prime}$ & ND & ND & ND \\
\hline M.O. & $69 \mathrm{M}$ & G.O.F. & Subtotal Gastrectomy & $2^{\circ} 35^{\prime}$ & ND & ND & ND \\
\hline S.M. & $19 \mathrm{M}$ & G.O.F. & Thoracotomy & $2^{\circ} 37^{\prime}$ & ND & ND & \\
\hline
\end{tabular}

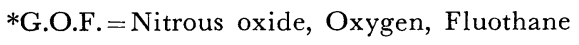

**G.O.E. $=$ Nitrous oxide, Oxygen Ether

$\dagger$ Preoperation $\dagger \uparrow 1 \mathrm{hr}$. Postoperation $\dagger \dagger \uparrow 24$ hrs. Postoperation 
ごとく尿中 17-OHCS 值が著明に増加しているにもかかわらず血中 AGTH 值の増加を証明できなかつた 症例もあり，両者の間に必ずしも相関が認められなかつた，なお，血中 ACTH 值が検定できた症例だけで， 尿中 17-OHCS 值との相関係数を求めると, 0.48 あった.

\section{2. 外科手術侵襲の血中 ACTH への影響}

Table 2 に示すように術前にはいずれも血中 AGTH 活性を認めず，執刀 1 時間後には13例中 8 例に 0.6 $\sim 19.1 \mathrm{mU} / 100 \mathrm{ml}$ plasma の增加を認めた．執刀 24 時間後には 1 例に $0.6 \mathrm{mU} / 100 \mathrm{ml}$ plasma の值を得たの みで，その他の症例では $\mathrm{ACTH}$ 值の増加を証明し得なかつた. 同時に血中 Cortisol を測定した6例につ いて血中 ACTH 值と比較すると Fig. 3 に示すごとく執刀 1 時間後に血中 ACTH 值の増加を認めた 4 例 においては，証明できなかつた 2 例よりも血中 Cortisol が高值であつた。症例 T.T. はクッシング症候群 のため右副腎摘除術をうけた患者であるが，術中 Hydrocortisone 80mg の点滴静注をうけていたにもかか わらず血中 AGTH 值の増加を認めた.

\section{3. 電気ショックの血中 $\mathrm{ACTH}$ への影響}

電気ショックを行なつた 2 例では Table 3 に示すでとく15分後にそれぞれ 4.9, $0.6 \mathrm{mU} / 100 \mathrm{ml}$ plasma と血中 AGTH の増加を認めた. なお症例 S.H. は治療上の目的で連続 3 回のショックを施行された例で

Fig. 3. Change of plasma ACTH and cortisol levels in surgical stress

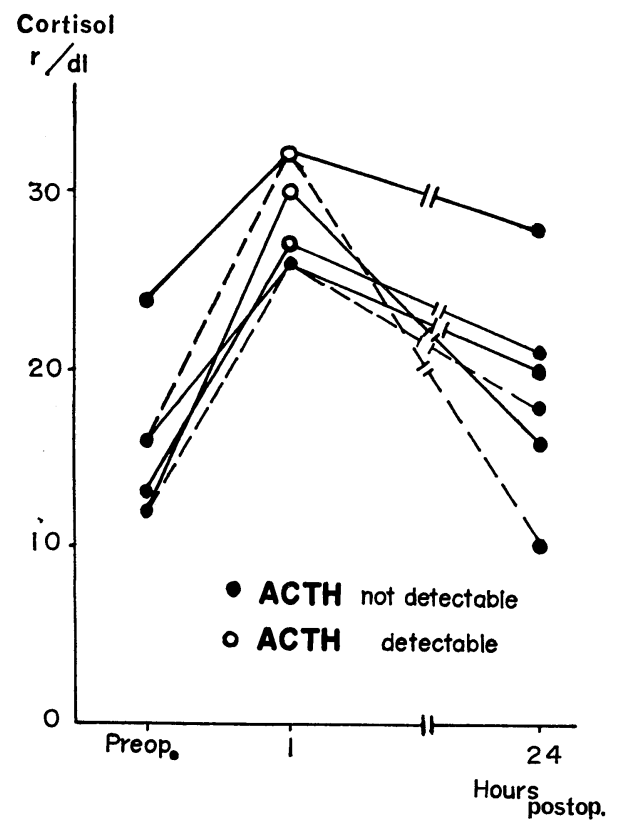

ある. 血中 ACTH 值と血中 Cortisol 值 とを比較してみると，15分後に血中 AGTH 值は増加しているが，血中 Cortisol は増加せ ず，30分後になり始めて血中 Cortisol の増 加がみられた。

\section{4. 血中 $\mathrm{ACTH}$ の日内変動}

正常人では Fig. 4 に示すごとく早朝に高 く午後に低い血中 $\mathrm{ACTH}$ の日内変動を認 めたが，副腎皮質過形成によるクッシング症 候群では明らかな日内変動が認められず，か えつて午後に高い症例もみられた。副腎性器 症候群においては Fig. 4 亿示すでとく正常 人と同様の日内変動が認められたが，午前 8 時と午後 6 時の較差は正常人に比して大きい 例を半数において認め，いわば拡大された日 内変動が存在することが知られた。アシシンン 病においては，10例中 8 例に於て著明な日内 変動を認めた。

副腎性器症候群およびアジソン病において 血中 ACTH と血中 Cortisol を同時に測定 した症例について両者の関係を見るために示

Table 3. Effect of electroshock on plasma ACTH and cortisol levels

\begin{tabular}{c|c|c|c|c|c|c}
\hline \hline \multirow{2}{*}{ Subjects } & \multicolumn{2}{|c|}{ before Electroshock } & \multicolumn{1}{|c|}{$15 \mathrm{~min}$. after Electroshock } & $30 \mathrm{~min}$. after Electroshock \\
\cline { 2 - 7 } & $\begin{array}{c}\text { ACTH } \\
(\mathrm{mU} / 100 \mathrm{ml})\end{array}$ & $\begin{array}{c}\text { Cortisol } \\
(\mu \mathrm{g} / \mathrm{dl})\end{array}$ & $\begin{array}{c}\text { ACTH } \\
(\mathrm{mU} / 100 \mathrm{ml})\end{array}$ & $\begin{array}{c}\text { Cortisol } \\
(\mu \mathrm{g} / \mathrm{dl})\end{array}$ & $\begin{array}{c}\text { ACTH } \\
(\mathrm{mU} / 100 \mathrm{ml})\end{array}$ & $\begin{array}{c}\text { Cortisol } \\
(\mu \mathrm{g} / \mathrm{dl})\end{array}$ \\
\hline \hline S.H. & - & 17 & 4.9 & 17 & - & 26 \\
S.N. & - & 13 & 0.6 & 12 & - & 25 \\
\hline
\end{tabular}


Fig. 4. Diurnal variation of plasma ACTH levels in normal subjects and patients with endocrine disorders

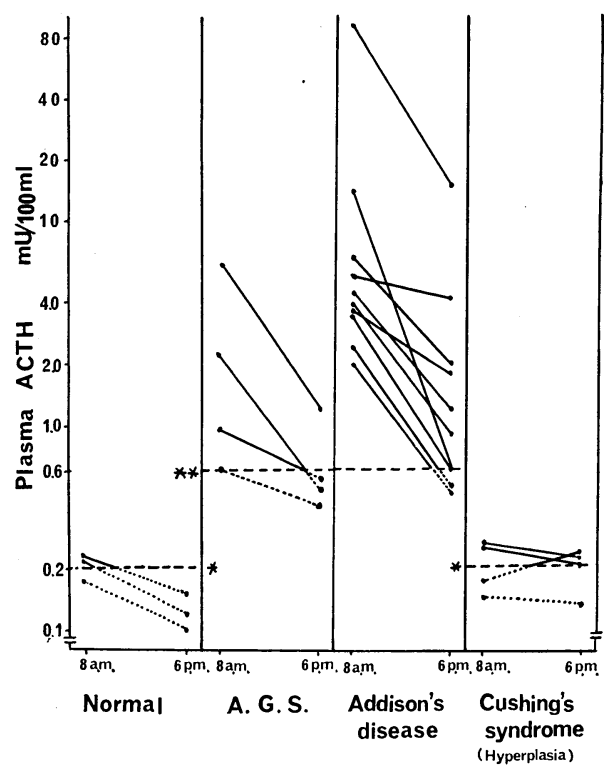

*Minimum Effective Dose by Aortic Method **Minimum Effective Dose by Femoral Method
Fig. 5. Diurnal variation of plasma ACTH and cortisol levels

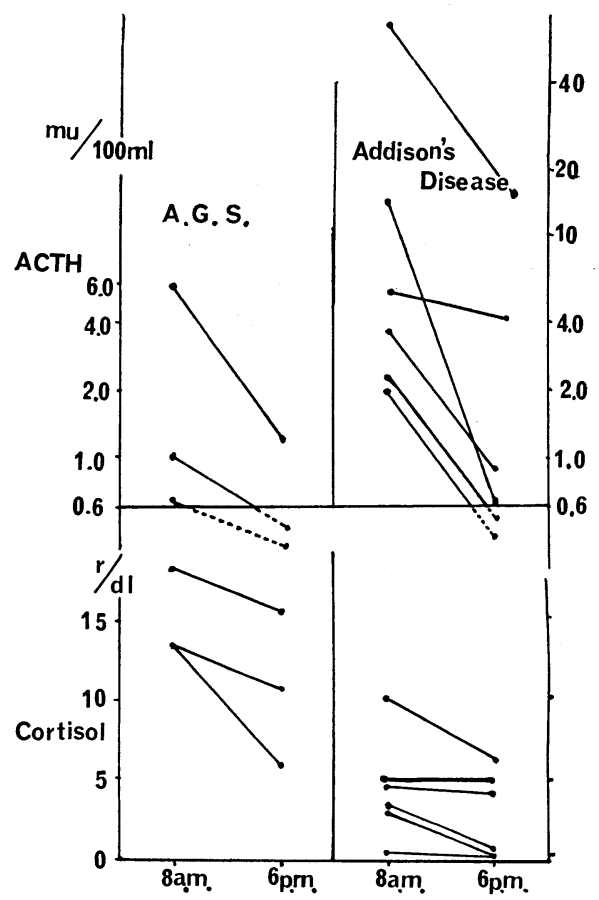

したのが Fig. 5 である. 副腎性器症候群においては血中 Cortisol 值は正常ないし正常下限で, すべての症 例において日内変動がみられたのにたいし，アジソン病においては血中 Cortisol 值は極めて低く, かつ日 内変動も 1 例を除き明らかでなかつた。

\section{5. 血中 $A C T H$ 亡血中 Cortisol の関係}

ストレス, 副腎性器症候群, アジソン病における 血中 ACTH 值と血中 Cortisol 值の関係はFig. 6 に示すごとくである. ストレスの際には血中 ACTH と Cortisol 值は共に增加したが両者の 間に必ずしも一定の相関は認められなかつた。副 腎性器症候群では血中 Cortisol 值に比し血中 ACTH 值がより高い傾向にあり，またアジソン 病においては ACTH 值は著るしく高いにもかか わらず血中 Cortisol は低值であつた.

$$
4 \text { 考按 }
$$

副腎皮質の $11 \beta$-Hydroxylase 阻止剤であるSU4885 (Metopirone, Methopyrapone) は Cortisol の生合成を抑制するため Feedback 機構を介して下垂体よりの ACTH 分泌が光進し，尿中に 11Desoxycortisol またはその代謝産物が増加する17)23)ので，てれを尿中 17-OHCS，あるいは17-KGS として 測定することにより下垂体の ACTH 分泌予備能を知りうる テロイドを指標とする方法は, 副腎皮質を介する間接的な方法であるため副腎皮質の反応性に影響を受ける 
可能性がある ${ }^{26}$. 従つて理論的には SU-4885 投与後の血中 ACTH の測定を行なうことが望ましいが，現 在の生物学的測定法は簡便でなく，かつ精度，感度も不充分であるためなお実用化の段階には至つていない．

Cushman ら゙ねは SU-4885 を犬に静注後血中 AGTH 活性の増加を認めたと報告しているが，人間では増

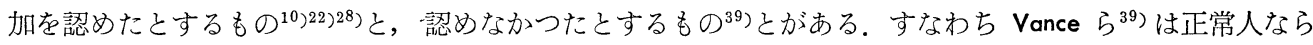
びにクッシング症候群患者に SU-4885 を点滴静注わよび経口投与後のいずれにおいても血中 ACTH 值の 増加を認めなかつたと報告している。同様にまたアジソン病 2 例においても血中 AGTH の増加をみなかつ たとし，Ganong ら ${ }^{9}$ 尖副腎摘除大で SU-4885 静注後血中 ACTH 值の上昇を認めたという報告と反対の 事実を示している. 一方 Liddle ら ${ }^{22)}$ は Carboxylic Resin にて ACTH を抽出, 測定する方法により, 正 常人に経口的に $500 \mathrm{mg} 4$ 時間每に投与をした場合， 8 時間後より血中 ACTH が上昇しはじめ 24 時間ない し72時間後には $1.0 〜 3.0 \mathrm{mU} / 100 \mathrm{ml}$ plasma になると報告している。著者も500mgを毎 4 時間経口投与する 方法により, 正常人 9 例全例に $0.6 \sim 4.0 \mathrm{mU} / 100 \mathrm{ml}$ plasma の血中 ACTH の増加を認め平均值士標準誤差 は $1.6 \pm 0.4 \mathrm{mU} / 100 \mathrm{ml}$ plasma であつた.

近年副腎皮質ステロイド剤は各種疾患の治燎に広く用いられているが，ての場合には Feedback 機構を 介して下垂体の $\mathrm{ACTH}$ 分泌が抑制され下垂体一副腎皮質系の機能低下をきたすととがしられている ${ }^{1316)}$. このような場合当然 SU-4885 投与に対する反応は不良となるととが予測され ${ }^{\left.16) 18202022)^{26}\right)}$, 本実験において も 5 例中 4 例に SU-4885 投与後血中 AGTH 值の増加を証明できなかつた。 また Graber ら ${ }^{13)}$, Meakin ら ${ }^{26}$ ) は関節りウマチ患者等に長期間副腎皮質ステロイド療法を行ないてれを中止するとまず下垂体機能が回復し ついで副腎皮質機能が正常にもどるととを明らかにした。 しかし SU-4885 に反応しない場合にも，ストレ

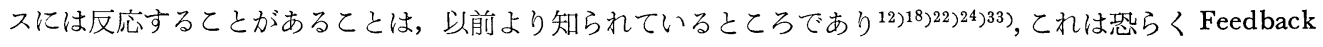
機構とストレスに対する分泌機構とが異なつたものであるてとを示唆するものであろう.

神経性食思不振症は精神的な原因に基づく食思不振が主因とされているが，しばしば内分泌異常もともな い汎下垂体機能低下症とまぎらわしい病像を呈する。本症における SU-4885 試験関しては, Gold ら ${ }^{12}$ は 3 例中 1 例に, Liddle $ら^{22}$ は 7 例中 3 例に, 河野ら ${ }^{20}$ は 5 例中 1 例に反応不良の例を認め, 栄養障害による 下垂体萎縮によるものであろうと推測している。しかしながら著者の測定した 5 例では全例に SU-4885 投 与後血中 ACTH 值の増加を認め, とくにそのうち2 例ではむしろ正常以上の反応がみられたが，てれら の例では尿中 17-OHCS 值の增加も極めて顕著であつた。 その原因としては, るい馊のため SU-4885 の体 重当りの投与量の相対的増加, 体内における ACTH 代謝の遅延, ACTH の放出低下により蓄積された下 垂体 ACTH の急激な放出などの可能性が考光られる。一方また本症においては AGTH の投与に対して 副腎皮質は正常ないしむしろ過剩に反応する例もある ${ }^{20}$ ととが知られており今後本症の正確な診断と共に， その下垂体副腎系の機能については更に検討を要する問題と考えられる.

一般にクッシング症候群のうち，副腎皮質過形成によるものでは SU-4885 に対し副腎皮質は過剩反応を 示し，副腎皮質腫演によるものでは無反応であるため，本試験は両者の鑑別診断に応用されている ${ }^{12220222244}$. Williams $~^{22)^{41}}$ は，副腎皮質過形成による本症で副腎全摘除術後血中コルチコイドが正常になるように補 償療法をおてなつたとてろ，血中 ACTH 值の著るしい増加を認めたと報告している，てのととより副腎 皮質過形成の症例では SU-4885 投与により血中 Cortisol 值が低下した場合当然血中 ACTH 值の正常 以上の増加がおこるものと予想された。しかし著者の測定した 2 例ではいずれも尿中 17-OHCS の著しい増 加があるにもかかわらず血中 ACTH の明らかな増加を認めなかつた．Miyake ら ${ }^{28)}$ は 3 例中 1 例に血中 ACTH 值の増加を証明したが, Vance $ら^{39}$ ， Garmendia $~^{11)}$ も著者と同様全例に増加を認めなかつたとし ている．てのように副腎皮質過形成によるクッシング症候群では，SU-4885 の投与により著明な尿中 17OHCS の反応がみられるにもかかわらず血中 ACTH の著明な増加が証明できない理由は明らかでないが， 肥大した副腎皮質はでくわずかの AGTH の増加に対しても充分 Cortisol 産生を高めうる可能性も否定で きない.また SU-4885 の 11 $\beta$-Hydroxylase 阻害は完全なものではないため副腎皮質が著明に反応した場合 には 11-Desoxycortisol のみでなく Cortisol るかなり産生され゙0)，てれが下垂体よりの ACTH の分泌を 
ある程度抑えるととも考慮されねばならない，一方副腎皮質腺腫に基くクッシング症候群では腫場よりの自 律性の Cortisol 過剩分泌のため下垂体および残存正常副腎皮質組織の萎縮をきたすととが知られている ${ }^{21)}$. 事実経験した症例 K.Mo.は副腎皮質腺腫のため右副腎摘除術をうけた後, 副腎発症を起しした症例で, 術 後 2 年たつても充分下垂体予備機能の回復がみられなかつた。 しかし他の症例 K. Ma は術前の ACTH 試 験に対する反応も良好で，SU-4885 投与に対しても血中 AGTH の増加がみられたが，乙れは正常副腎組 織の萎縮が起つていなかつたものと考朰れる，以上要するにクッシング症候群に対する副腎皮質および下 垂体の機能的関係はなお未解決の点が多く今後の研究が必要であると考えられる.

SU-4885 投与後の血中 ACTH 值と尿中 17-OHCS 増加の絶対值とを対比させてみると, 副腎皮質過形 成によるクッシング症候群のでとく尿中 17-OHCS の増加があるにもかかわらず血中 ACTH 值の明らかな 增加を証明できなかつた症例もあり，必ずしも一定の相関は認められなかつた。

外科手術侵襲時に血中 $\left.17-\mathrm{OHCS}^{36}{ }^{38}\right)$ 加増加するてとは以前よりよく知られていたが，血中 ACTH の分 泌充進が証明されたのは比較的最近のととである3 $\left.3^{7}\right)^{22} 22^{29}$. 著者の実験では手術開始一時間後に13例中 8 例 で明らかな血中 ACTH の増加を認めたが，24時間後には低下し一例で血中 ACTH の増加を証明しえた のみであつた．Cooper らきも手術終了後30分で血中 ACTH の増加がるられ，4時間後には低下しはじめ 術後24時間には術前の值にもどることを認めた。また Estep ら7)も執刀 1 時間後に血中 ACTH の増加を認 め同時に血中 17-OHCS, 尿中 17-OHCS も上昇しているととを明らかにした。 さらにまた手術中に Cortisol の大量点滴静注を行なつても血中 ACTH の增加は抑制されなかつたため, 開腹術のような大きな手術侵襲 によるACTH 分泌は Feedback 機構によつて制約されないという見解を発表している. 著者の実験でも 副腎皮質過形成によるクッシング症候群のため右副腎摘除術をうけた症例では, 術中 2 時間にわたり Cortisol 80mg の点滴静注をうけたが血中 ACTH 值の增加が認められた. Liddle ら ${ }^{22}$ も電気ショックによる血 中 17-OHCS の上昇は大量の副腎皮質ステロイドによつても抑制されなかつたとしている。一方，動物実 験で，Yates ら ${ }^{42}$ はラットに開腹術により增加する程度の血中 Corticosterone 濃度になるように，充分量 の Corticosterone をあらかじめ投与しておくと下垂体-副㹂皮質系の開腹術に対する反応が全くみられなく なるととを認め，ストレスの際には，Feedback 機構がよりたかい血中コルチコイド濃度で作用すするように 修正 (Reset) されるものであると推諭している。しかしながら人間では，少くとも開腹術のでとき大きな ストレスに対してはかような “Resetting”の現象は認められていない。

なお外科手術侵襲中の血中 17-OHCS の上昇は手術にもとずく肝流血量の低下および肝機能低下のため 肝臓でのステロイド代謝が障害されるととが一つの原因であるとする主張もある ${ }^{36383}$. Cooper ら ${ }^{33}$ ，あるい は著者の実験にみられるでとく術後24時間の血中 AGTH 值は術前の值にもどつているにもかかわらず血中 コルチコイド值はなお高值であつた原因の一つとしててのような Cortisol の代謝遅延が考えられる。しか しまた持続した ACTH の分泌增加か㨽腎の反応性を高め正常の ACTH に対しても正常以上に副腎皮質 が反応したためとも考光られる。

下垂体一副緊皮質系機能の日内変動については, Pincus $\left.{ }^{35}\right)$ にり尿中 17-KS 值は昼間が夜間より高いとと が報告されて以来血中 17-OHCS $\left.\left.\left.{ }^{27}\right)^{32}\right)^{34}\right)^{37}$ )，尿中 17-OHCS ${ }^{527) 37)}$ 亿も同様の日内変動が認められるととが 明らかにされた。乙のような日内変動をきたす原因に関して Perkoff ら ${ }^{34}$ は，第一に血中よりの Cortisol 消失速度の变動, 第二に ACTH に対する副腎の反応性の変動, 第三に中枢神経系に存在する ACTH 分 泌機構による血中 AGTH の変動の三つの可能性を指摘した，そして彼等は，Cortisol 消失速度は昼夜 とも不変であり, 夜間の副腎の ACTH に対する反応性の低下は内因性 ACTH 分泌減少による二次的な ものであるととを明らかにし，意識障害，睡眠時間の転換，脳障害の場合に血中 17-OHCS の日内変動が 消失することから ACTH 分泌の中枢支配自体に日内変動があるものと推論した．乙の副腎皮質機能の日 内変動が ACTH 分泌の変動によるものであるとする仮説は，最近 Ney ( $^{29}$ 亿より直接血中 ACTH を測 定するととによつて証明された。すすおち，正常人では午前 6 時の血中 ACTH 值は平均 $0.25 \mathrm{mU} / 100 \mathrm{ml}$ plasma で, 夕方 6 時には血中 17-OHCS の低下とともに血中 ACTH 值も $0.11 \mathrm{mU} / 100 \mathrm{ml}$ plasma と低 
下するととを明らかにした．著者の成績も午前 8 時 $0.23 \mathrm{mU} / 100 \mathrm{ml}$ plasma 以下，午後 6 時 $0.20 \mathrm{mU} / 100 \mathrm{ml}$ plasma 以下となり同様の結果を得ている。一方副腎皮質過形成によるクッシング症候群では血中 17-OHCS 值が高く，しかも日内変動が消失しているととが診断上有用な所見とされているが吕，Ney ${ }^{29}$ は本症の血 中 ACTH 值は正常人に比較して一部重なり合いがあるが年前 6 時の平均值は $0.62 \mathrm{mU} / 100 \mathrm{ml}$ plasma と有 意に高く，しかも日内変動が明らかでないととを認めた。著者も同様に本症において明らかな日内変動を認 めることができなかつた．本症においてはおそらく正常值よりわずかに高い AGTH 分泌が一日中持続して いるととが考えられる．乙のことは正常人に微量の ACTH を持続的に点滴静注すると，血中 17-OHCS は上昇し日内変動も消失し，しかも AGTH に対する副腎皮質の反応性がたかまるという報告 ${ }^{3132}$ 亿一致 するものである，従つて本症では抑制試験にみられるように Feedback 機構の障害 ${ }^{22}{ }^{25}$ とともに，日内変 動の調節機構にも何らかの異常があるものと考学られる.

副腎性器症候群では Cortisol 生合成の障害のため Feedback 機構を介し血中 ACTH が著明に増加し ているてとは，すでに第一編で明らかにした通りである。しかし著明な代償性 AGTH 分泌充進を伴う本症 で，果して日内変動が保たれているか否かは従来明らかでなかつた。著者は４例の本症において正常人と同 様に早朝に高く午後に低い ACTH の日内変動を認め，かつその較差は正常人に比較しはるかに大きいとと を明らかにした．また本症と同じく代償性の ACTH 分泌充進をきたすアジソン病においても，同様な日内 変動が観察されたが早朝の值はアシシンン病では副腎性器症候群よりも高く, 従つて, 日内変動の較差も著しく 大であつた. Graber $\left.ら^{13}\right)^{14}$ ) , アジソン病ならびに長期間のコルチコイド療法中止後の症例で, 血中 AC'TH 值の日内変動を認め, またアシシン病の患者に通常の血中 Cortisol 值以下で午前 6 時の血中 17-OHCS 值 を午後 6 時より高くなるよう Cortisol を投与しても日内変動は保持されるてとを明らかにした，かつ，て のような状態でも著者の成績と同様正常よりも較差の大きい日内変動を報告している．てのようないわば拡 大された日内変動をきたす理由は明らかでないが，正常では早朝の AGTH 分泌充進はそれに伴う Cortisol 産生增加によつてある程度抑制され一定の範囲に調節されるが，副腎皮質の Cortisol 産生分泌に障害 がある場合にはての調節がなされないため, 極めて著明な血中 ACTH の增加をきたすのではないかと考え られる。

日内変動と Feedback 機構との関係については著者は実験を行なつていないが，Nichols ら ${ }^{30}$ は Dexamethasone を真夜中に投与した場合には，午前 8 時，あるいは午後 4 時に投与した場合より抑制が強いて とを見出し，Feedback 機構による ACTH 分泌の抑制にも日内変動のリズムが影響しているてとを明ら かにしている，また日内变動とストレスとの関係はなお明らかでないが，Claytonらうは ACTH 放出作用 を有するVasopressin 誘導体への反応は星と夜とで異なることを見出しているので，ストレスに対する反 応にも日内変動のリズムが影響するてとは充分考えられる，てのように Feedback 機構，ストレスによる 分泌機構，日内変動の機構はわ互いに関連しつつ ACTH の分泌調節を行なつているものと考朰れる.

\section{5 結 語}

下垂体摘出ラット副腎静脈血中 Corticosterone の増加を指標とした生物学的測定法を用い， SU-4885 や ストレスの血中 ACTH への影響を観察するとともに, ACTH 分泌の日内変動についても検討を加えた.

1. SU-4885 1 日 $3 \mathrm{~g} 6$ 回分割経口投与により (1) 正常人 9 例では平均值士標準誤差 $1.6 \pm 0.4 \mathrm{mU} / 100 \mathrm{ml}$ plasma (0.6〜 4.0mU/100ml plasma) 亿達する血中 ACTH の增加を認めた。（2)副腎皮質ホルモン療法をお こなつた症例につきその中止後 AGTH の測定をおてなつたとてろ 5 例中 1 例にのみ血中 AGTH 值の増加 を認めた。(3)神経性食思不振定 5 例はいずれも明らかな ACTH の增加を示しそのうち 2 例ではとくに高值 で尿中 17-OHCS も著しく増加していた。（4)クッシング症候群では，副腎皮質過形成によるもの2例で SU-4885 投与後血中 ACTH の増加を証明できず，かえつて副腎皮質腺腫による1例で増加を認めた。し かし他の副腎皮質腺腫の 1 症例では術後 2 年以上血中 ACTH 值の増加を証明できなかつた。(5)その他の疾 患のうちではとくに肝硬変症 1 例でかなり著明な血中 AGTH の増加を認めた。(6) SU-4885 投与後の尿中 
17-OHCS 值と血中 ACTH 值の関係については，副腎皮質過形成によるクッシング症候群のごとく例外も あつたが一般に尿中 17-OHCS の高い例では血中 ACTH 值も高い例が多かつた.

2. 外科手術侵襲時執刀開始 1 時間後に血中 ACTH 值を測定したところ 13 例中 8 例に 0.6〜 19.1 $\mathrm{mU} / 100$ $\mathrm{ml}$ plasma の血中 $\mathrm{ACTH}$ 值の増加を認めた. 術後24時間には, 13例中 1 例にのみ血中 AGTH の増加を 証明しえた，血中 Cortisol を同時に測定した 6 例では，血中 AGTH 值の増加を認めた例が，血中 Cortisol 值も高い傾向にあつた。

3. 精神分裂病患者 2 例に電気ショックをあたえた際 2 例とも血中 ACTH の増加がみられた.

4. AGTH の日内変動について検討したところ正常人においては早朝に高く午後に低い日内変動を認め たが，副腎皮質過形成によるクッシング症候群では明らかな日内変動を認めなかつた. 副腎性器症候群 4 例, アジソン病10例ではいずれも日内変動を認め, しかも午前, 午後の較差が正常人よりはるかに大であつた.

擱筆するに当り御恩篤なる御指導と御校閲を賜つた恩師深瀬政市教授，三宅儀前教授に深甚の謝意を表し ます。また終始御助言と御鞭撻を戴いた井村裕夫講師に深く感謝致します。な拉諸症例の収集に御協力頂き ました野手信哉岐阜大学助教授, 西村敏夫講師（現高知赤十字病院長），静岡県立中央病院内科医長祖父江 鮮博士，和歌山赤十字病院内科医長羽山恒人博士に篤く御礼申し上げます．また本田弘，佐古伊康両学士の 御協力に感謝いたします.

\section{文献}

1) BLISS, E.L., G.J. MIGEON, K. EIK-NES, A.A. SANDBERG and L.T. SAMUELS : Metabolism, $3: 493$, (1954). $\quad$ 2) CLAYTON, G.W., L. LIBRIK, R.L. GARDNER and G. GUILLEMIN : J. Clin. Endocr., 23 : 975, (1963). $\quad$ 3) COOPER, C.E. and D.H. NELSON : J. Clin. Invest., 41 : 1599, (1962). $\quad$ 4) CUSHMAN, P., G.D. WESTERMANN, W.J. ATHOS and J.G. HILTON : Endocrinology, $73: 529$, (1963). $\quad$ 5) DOE, R.P., J.A. VONNES and E.B. FLINK : J. Clin. Endocr., $20: 253$, (1960). $\quad$ 6) EKMAN, H., B. HÅKANSSON, J.D. McGARTLY, J. LIHMANN and B. SJÖGREN : J. Glin. Endocr., $21: 684$, (1961). $\quad$ 7) ESTEP, H.L., D.P. ISLAND, R.L. NEY and G.W. LIDDLE : J. Clin. Endocr., $23: 419$, (1963). 8) FARMER, T.A., JR., S.R. HILL, JR., J.A. PITTMAN, JR. andJ.W. HEROD, JR. : J. Glin. Endocr., 21 : 433, (1961). 9) GANONG, W.F. and E.M. GOLD : The Physiologist, $3: 63$, (1960). 10) GARMENDIA, F., W.E. VAUBEL und E.F. PFEIFFER : Klin. Wochen., $41: 317$, (1963). 11) GARMENDIA, F., W.E. VAUBEL, H. BUBSER und E.F. PFEIFFER : Klin. Wochen., $41: 321$, (1963). 12) GOLD, E.M., J.R. KENT and P.H. FORSHAM : Ann. Int. Med., 54 : 175, (1961). 13) GRABER, A.L., R.L. NEY, W.E. NIGHOLSON, D.P. ISLAND and G.W. LIDDLE : J. Glin. Endocr., $25: 11$, (1965).

14) GRABER, A.L., J.R. GIVENS, W.E. NIGHOLSON, D.P. ISLAND and G.W. LIDDLE : J. Clin. Endocr., 25 : 804, (1965).

15) HÖGKFELT, B. and R. LUFF : Acta Endocr., $32: 177$, (1959). 16) HOLUB, D.A., J.W. JAILER, J.I. KITAY and A.G. FRANTZ : J. Clin. Endocr., $19: 1540$, (1959). $\quad 17)$ JENKINS, J.S., L. POTHIER, W.J. REDDY, D.H. NELSON and G.W. THORN : Brit. Med. J., 1. : 398, (1959).

KAPLAN, N.M. : J. Clin. Endocr., $23: 953$, (1963). 19 河野剛：下垂体 ACTH 予備能検查, 三宅儀編, 内分泌疾患 1, (1964). 20）河野 剛, 岩井一義, 井村裕夫, 八幡三喜男, 田村陽市, 遠藤治郎, 多田敏明, 松下六良, 吉見輝也, 松田孝之, 佐古伊康 : 最新医学, $19: 165,(1964)$. 21) KYLE, L.H., R.J. MEYER and J.J. CANARY : New Eng. J. Med., 257 : 57, (1957). 22) LIDDLE, G.W., D.P. ISLAND and C.K. MEADOR : Res. Prog. Hor. Res., $18: 125$, (1962). 23) LIDDLE, G.W., D.P. ISLAND, E.M. LANGE and A.P. HARRIS : J. Clin. Endocr., 18 : 906, (1958). 
24) LIDDLE, G.W., H.L. ESTEP, J.W. KENDAL, JR., W.C. WILLIAMS, JR. and A.W. TOWNES : J. Glin. Endocr., 19 : 875, (1959).

25) LIDDLE, G.W. : J. Glin. Endocr., 20 : 1539, (1960), 26) MEAKIN, J.W., M.S. TANTONGGO, J. GRABBE, T.B. BAYLES and D.H. NELSON : Am. J. Med., 29 : 459, (1960). 27) MIGEON, C.J., F.H. TYLER, J.P. MAHONEY, A.A. FLORENTIN, H. GASTLE, E.L. BLISS and L.T. SAMUELS : J. Clin. Endocr., 16 : 622, (1956). R.L., N. SHIMIZU, W.E. NIGHOLSON, D.P. ISLAND and G.W. LIDDLE : J. Glin. Invest., 42 : 1669, (1963). 30) NICHOLS, T., G.A. NUGENT and F.H. TYLER : J. Clin. Endocr., 25 : 343, (1965). $\quad 31)$ NUGENT, C.A., K.B. EIK-NES, L.T. SAMUELS and F.H. TYLER : J. Glin. Endocr., 19 : 334, (1959). $\quad$ 32) NUGENT, G.A., K.B. EIK-NES, H.S. KENT, L.T. SAMUELS and F.H. TYLER : J. Glin. Endocr., $20: 1259$, (1960).

33) OPPENHEIMER, J.H., L.V. FISHER and J.W. JAILER : J. Clin. Endocr., 21 : 1023, (1961). 34) PERKOFF, G.T., K.B. EIK-NES, G.A. NUGENT, H.L. FRED, R.A. NINER, L. RASH, L.T. SAMUELS and F.H. TYLER : J. Clin. Endocr., 19 : 432, (1959).

35) PINGUS, G. : J. Glin. Endocr., 3 : 195, (1943). 36) SANDBERG, A.A., K.B. EIK-NES, L.T. SAMUELS and F.H. TYLER : J. Glin. Invest., 33 : 1509, (1954). 37) SHOLITON, L.J., E.E. WERK, JR. and R.T. MARNELL : Metabolism, 10 : 632, (1961). 38) TYLER, F.H., C.D. SGHMIDT, K.B. EIK-NES, H. BROWN and L.T. SAMUELS : J. Glin. Invest., 33 : 1517, (1954).

39) VANCE, V.K., W.J. REDDY, D.H. NELSON and G.W. THORN : J. Clin. Invest., $41: 20$, (1962). 40) WAXMAN, S.H., D.F. TIPPIT and V.C. KELLEY : J. Glin. Endocr., 21 : 943, (1961). 41) WILLIAMS, W.C., JR., D.P. ISLAND, R.A.A. OLDFIELD, JR. and G.W. LIDDLE : J. Clin. Endocr., 21 : 426, (1961). 42) YATES, F.E., S.E. LOEMAN, D.W. GLENISTERand M.F. DALLMAN : Endocrinology, 69 : 67, (1961). 